\title{
Barebacking among men who have sex with men recruited through a Swedish website: associations with sexual activities at last sexual encounter
}

R C Berg (rib@nokc.no)1, R Tikkanen², M W Ross³

1. The Norwegian Knowledge Centre for Health Services, Oslo, Norway

2. University of Gothenburg, Gothenburg, Sweden

3. University of Texas, Houston, United States of America

Citation style for this article:

Berg RC, Tikkanen R, Ross MW. Barebacking among men who have sex with men recruited through a Swedish website: associations with sexual activities at last sexual encounter. Euro Surveill. 2013;18(13):pii=20438. Available online: http://www.eurosurveillance.org/ViewArticle.aspx?Articleld=20438

The research topic of barebacking emerged in the mid1990s. Since then, a multitude of studies, largely from the United States, have produced invaluable knowledge of factors that help explain the behaviour among men who have sex with men (MSM), and that may contribute to HIV risk reduction programming and advice to counsellors working with barebackers. Given the scant empirical research about barebacking among European MSM, we conducted a survey among 3,634 MSM recruited through a web community in Nordic countries. The objectives of the study were twofold: to describe the sexual activities associated with barebacking behaviour at last sexual encounter, and to evaluate the relationship of barebacking with relevant variables. Men who reported barebacking $(n=356)$ and men who did not $(n=3,278)$ were compared. On the basis of the results of the analyses, the sociosexual profile of barebackers drawn was one that is at increased risk of acquiring human immunodeficiency virus (HIV) and other sexually transmitted infections due to their sexual practices, particularly unprotected anal intercourse, but also group sex and rimming. In a multivariate logistic regression analysis, the likelihood of engaging in barebacking was higher for MSM who reported more frequent HIV testing (odds ratio $(O R)=5.16)$, a higher number of female sex partners $(O R=16.80)$, using gay cruising places $(O R=1.51)$ and gay chat rooms $(O R=2.11)$.

\section{Introduction}

After nearly two decades of research about barebacking, the term, which first emerged in the gay press in the mid-1990s [1], remains inconsistently operationalised. While some researchers specify it as intentional condomless anal intercourse among men who have sex with men (MSM) in human immunodeficiency virus (HIV) risk contexts [2-5], others define it as intentional unprotected anal intercourse (UAI) with a non-primary male partner [6,7], or as intentional UAI with a casual or primary partner of any HIV status [8]. A 2009 review [9] concluded that the term had evolved semantically and appeared to hold different meanings across serostatus and cultural groups. Based on interviews with 120 MSM regarding the term barebacking, CarballoDiéguez and colleagues summarised that MSM by and large understood it as 'condomless anal sex', but that much variation existed. The researchers concluded by suggesting a more HIV prevention-focused distinction between sexual behaviours that were 'intentional and may result in HIV-primary transmission from those that are not' [2].

Although the term barebacking remains elusive and in some communities may have passed into more general usage as a neologism for condomless anal intercourse between men [10-12], research on the issue has produced invaluable knowledge of factors that help explain this behaviour among MSM, and that may contribute to HIV risk reduction programming and advice to counsellors working with barebackers. Existing literature on barebacking was recently summarised in a comprehensive review [9]. With a view to understand reasons for bareback sex, the author positioned empirically identified factors associated with the behaviour in a conceptual framework. It showed that bareback sex was associated with lower age, lower educational attainment, being HIV-positive, recreational drug use, gay community involvement and type of sociocultural environment. Barebacking was also closely associated with both engaging in unprotected sex and having casual partners, which raise added concerns with regard to transmission of HIV and other sexually transmitted infections (STIs) [9].

Men who have sex with men and human immunodeficiency virus

Despite the small size of this community, MSM are the population most severely affected by HIV in European Union and European Economic Area (EU/EEA) countries, accounting for $38 \%$ of all new HIV diagnoses in 2010 [13]. Worrying trends show that from 2004 to 2010, the number of HIV diagnoses in this group increased 
by $42 \%$, from 7,621 to 10,854 [13]. Surveys mapping behavioural surveillance in Europe $[14,15]$ reveal that just over half (14 of 27) of EU/EEA countries report an established behavioural surveillance system, complicating the evaluation of development in risk behaviour. Trends recorded through behavioural surveillance can offer important insights into corresponding trends in disease incidence over time [14]. Trend data on sexual behaviours among MSM are scarce, and none include information on intention to practice UAI $[14,16]$. However, according to several reports increases in HIV diagnoses among MSM are linked to an increase in high-risk sexual behaviour (e.g. $[17,18])$. In England, Dodd et al. [18] identified a significant increase in reporting unprotected anal sex, including UAI with partners of an unknown or discordant serostatus, in recent years. In many countries, the resurgence in HIV diagnoses is linked to STIs [19-21], including syphilis incidence, which in Sweden between 2000 and 2007 was up to 28 times higher among MSM than in the general male population [22].

Surprisingly, little research exists on the range of barebackers' sexual behaviours, beyond their engaging in unprotected sex and having casual partners, that can serve to inform HIV prevention initiatives. As an exception, Léobon and Frigault [23], who have completed one of the few studies that exist about barebacking among MSM in Europe, found that MSM who reported engaging in bareback sex were also more likely to report rimming and group sex. The study results suggested that one in four men engaged in bareback sex in the past year and that compared to respondents from the other three sites, respondents from the bareback website reported having significantly more bareback sex with casual partners [23].

In general, despite a growing body of literature on barebacking, with the exception of Elford and colleagues [24], Léobon and Frigault [23], and Léobon et al. [8], few studies have examined barebacking among European MSM; still fewer have considered the characteristics of last sexual encounter related to bareback sex. Single-event recall like last sexual encounter helps minimise recall bias and is a valid representation of sexual behaviours over longer periods of time [25]. Our objectives were to (i) estimate the occurrence of barebacking and describe sexual activities associated with bareback sex at last sexual encounter among MSM and (ii) to evaluate the relationship of barebacking with HIV testing, having sex with women, and the use of gay cruising places and chat rooms.

\section{Methods}

A full description of the study methods has been previously reported [26]. In brief, study eligibility requirements included being MSM, above the age of 15 , and having Swedish as the preset language in the Qruiser community, the largest online community in Nordic countries for lesbian, gay, bisexual and transgender persons. Through Qruiser, eligible MSM were invited
FIGURE

Flowchart of survey participation, March-April 2008

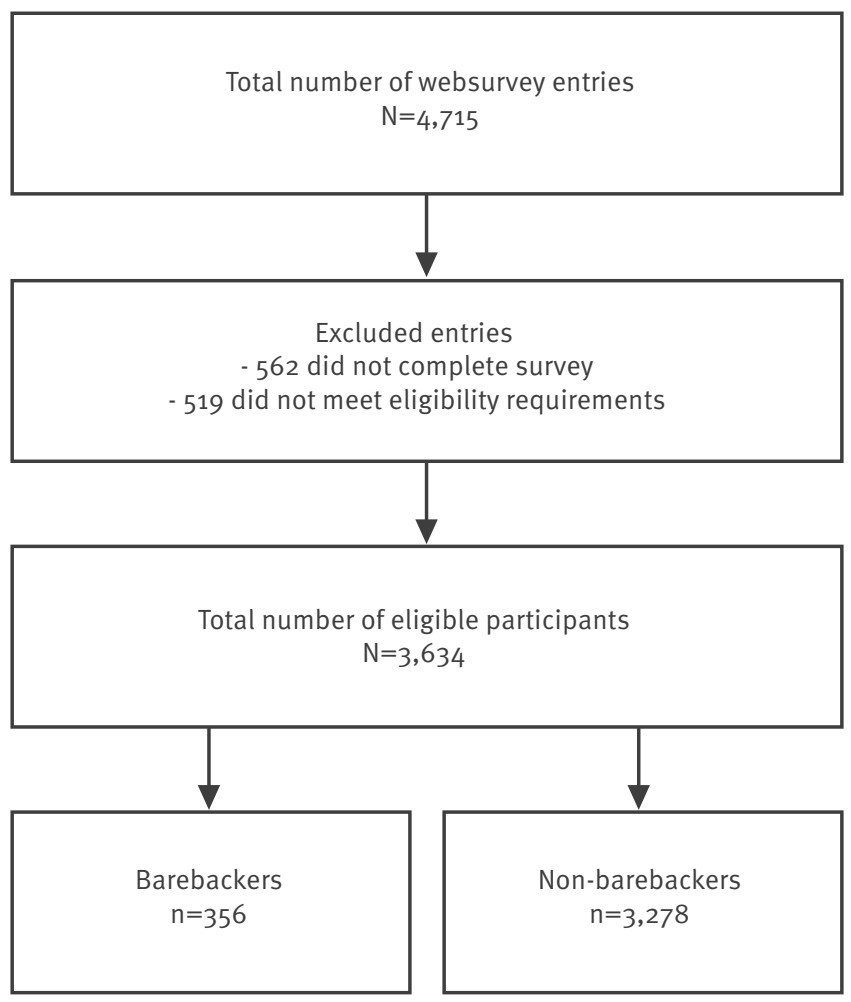

to complete a socio-behavioural survey. The website's banner and pop-up advertisements which invited study participation stated that study completers were eligible to enter into a drawing of travel vouchers. The survey was available for two weeks in March-April 2008, during which time about $50 \%$ of the Qruiser community's 51,814 member accounts that met the criteria for being included in the study, logged into the site at least once.

The survey was divided into four sub-sections, including one covering socio-demographic information. The second and third subsections focused on health and sexual behaviours, such as the last sexual encounter with a man. In the final section, two sets of questions were asked about the respondents' thoughts about HIV and their need for information and services concerning HIV, STIs, and safer sex. For the present analyses, descriptive statistics and bivariate analyses were used to evaluate sexual activities at last sexual encounter related to barebacking. In addition, for objective two, four predictor variables implicated in HIV/STI transmission were assessed in univariate logistic regression models: HIV testing, having sex with women, the use of gay cruising places, and the use of chat rooms. Variables with a $\mathrm{p}$ value $<0.001$ were included in a multivariate logistic regression model and the odds ratio (OR) with their respective $95 \%$ confidence intervals 
Group differences for men who have sex with men who engaged in barebacking $(n=356)$ and those who did not engage in barebacking $(n=3,278)$, recruited through a web community in Nordic countries, 2008

\begin{tabular}{|c|c|c|c|}
\hline Variables (last sexual encounter) & $\begin{array}{l}\text { Engaged in barebacking } \\
(\%)^{\mathrm{a}}\end{array}$ & $\begin{array}{l}\text { Did not engage in barebacking } \\
(\%)^{\mathrm{a}}\end{array}$ & $\begin{array}{l}\text { Test for difference } \\
\text { p value }\end{array}$ \\
\hline Found sex partner through internet & $142(57.9)$ & $840(47.0)$ & 0.002 \\
\hline Had sex at cruising location & $49(13.8)$ & $314(9.6)$ & 0.015 \\
\hline Had sex with $\geq 2$ people & $59(16.6)$ & $274(8.4)$ & $<0.001$ \\
\hline Had sex with unknown casual partner & $141(39.6)$ & 948 (28.9) & $<0.001$ \\
\hline Engaged in UAI & $166(46.6)$ & $792(24.2)$ & $<0.001$ \\
\hline Engaged in rimming & $138(38.8)$ & $823(25.1)$ & $<0.001$ \\
\hline Engaged in fisting & $21(5.9)$ & $52(1.6)$ & $<0.001$ \\
\hline Engaged in oral sex & $301(84.5)$ & $2,682(81.9)$ & 0.243 \\
\hline Received semen in mouth & $100(28.1)$ & $604(18.4)$ & $<0.001$ \\
\hline Ejaculated in partner's mouth & $72(20.2)$ & $592(18.1)$ & 0.348 \\
\hline Engaged in mutual masturbation & $212(59.5)$ & $2,079(63.4)$ & 0.148 \\
\hline Communicated about HIV-status & $98(58.3)$ & $732(43.0)$ & $<0.001$ \\
\hline
\end{tabular}

HIV: human immunodeficiency virus; UAI: unprotected anal intercourse.

a Percentages were calculated on the basis of the number of cases for which information was available.

(CI) were calculated using SPSS 18.0. In these analyses, the question that served as the outcome variable (barebacking) was worded 'Have you during the past year had unprotected anal intercourse with a casual partner with whom you beforehand decided not to use a condom?' in line with similar studies $[6,7]$. The protocol for the study was approved by the institutional review board at the University of Gothenburg.

\section{Results}

There were 4,715 websurvey entries. Of these, 3,634 were eligible entries from MSM who had been sexually active in the past year $(1,081$ men either did not complete the survey or failed to meet the eligibility requirements). The sample was predominantly gay (74\%), HIV-negative (85\%) and almost $96 \%$ lived in Sweden. Nearly ten percent of the respondents $(n=356)$ said they had engaged in barebacking in the past year (this was a binary 'yes'/'no' question and we did not ask frequency of barebacking, which likely varied). Additional details regarding the response rate and sample have previously been reported elsewhere [26].

\section{Sexual activities at last sexual contact associated with barebacking} In terms of objective one, situations regarding last sexual encounter, barebacking was associated with finding the sexual partner through the internet, having sex at a cruising location, having sex with two or more people, having sex with an unknown casual partner, and engaging in unprotected anal intercourse. Additionally, sexual activities associated with barebacking at last sexual contact included rimming, fisting, and oral sex with sperm taken in the mouth. At last sexual contact, barebackers were also more likely to have communicated about HIV-status with their partner. For all bivariate analyses, $p<0.01$, except for having had sex at a cruising location where $p=0.015$. The association between barebacking and oral sex, ejaculating in the partner's mouth, and mutual masturbation was not statistically significant (p>0.05) (see Table 1).

Specifically, the analyses showed that MSM who reported bareback sex were more likely to have found their last sex partner through the internet (142/245) than non-barebackers $(840 / 1,786)$ and had last sex at a gay sauna, sex cinema or other cruising area (49/356 barebackers and 314/3,278 non-barebackers). For $59 / 356$ of barebackers and 274/3,278 of non-barebackers, the last sexual encounter involved two or more partners, and barebackers were also more likely to have engaged in sex with an unknown casual partner $(141 / 356$ vs $948 / 3,278)$. Compared to men not reporting bareback sex, barebackers were more likely to have communicated about HIV-status at last sexual contact (see Table 1).

\section{Predictors of barebacking}

Results for the second objective showed that all four predictor variables (HIV testing, having sex with women, using gay cruising places, using chat rooms) were significantly associated with barebacking in the 
TABLE 2

Multivariate logistic regression analysis summary for predicting barebacking

\begin{tabular}{|c|c|c|c|c|}
\hline Variables & Beta weight & Wald chi-squared & $\begin{array}{l}\text { Odds ratio } \\
(95 \% \mathrm{Cl})\end{array}$ & $\mathrm{p}$ value \\
\hline HIV tests & 1.64 & 167.99 & $\begin{array}{c}5.16 \\
(4.03-6.61)\end{array}$ & $<0.001$ \\
\hline Female sex partners in past year & 2.82 & 490.83 & $\begin{array}{c}16.80 \\
(13.09-21.56) \\
\end{array}$ & $<0.001$ \\
\hline Used cruising location in past year & 0.41 & 10.83 & $\begin{array}{c}1.51 \\
(1.18-1.94) \\
\end{array}$ & $<0.001$ \\
\hline Used gay chat weekly & 0.75 & $35 \cdot 52$ & $\begin{array}{c}2.11 \\
(1.65-2.70)\end{array}$ & $<0.001$ \\
\hline
\end{tabular}

$\mathrm{Cl}$ : confidence interval; HIV: human immunodeficiency virus

univariate logistic regression analyses (all p<0.001). Men who reported barebacking within the past year reported a mean of 6.5 (standard deviation $(S D)=9.7$ ) HIV tests compared to $4.2(\mathrm{SD}=5.3)$ tests among men who did not report bareback sex. The mean number of female sex partners in the past year was less than one for both barebackers and those not reporting bareback sex $(0.9(S D=2.6)$ vs $0.50(S D=2.0))$. In total $41.3 \%$ $(1,256 / 3,044)$ of non-barebackers reported using a cruising location in the past year, while the corresponding number for barebackers reporting this behaviour was 63.9\% (209/327). Similarly, 43.0\% (153/356) of barebackers said they used gay chat rooms weekly, while $29.7 \%(975 / 3,278)$ of their non-barebacking counterparts reported this activity.

In the multivariate logistic regression analysis, the likelihood of engaging in barebacking was higher for those MSM who reported more frequent HIV testing in the past year $(O R=5.16)$, a higher number of female sex partners in the past year $(O R=16.80)$, using gay cruising places in the past year $(O R=1.51)$, and using gay chat rooms at least weekly $(O R=2.11)$. Confidence intervals and final beta weights are shown in Table 2 . The Cox and Snell's pseudo R-square was 0.479 and the Hosmer-Lemeshow goodness of fit chi-square test was 243.6, degrees of freedom $(d f)=3$, p<0.001. Keeping in mind that a multivariate logistic regression is considered to represent a good fit with the data when the chisquare is statistically non-significant, the four-variable predictor model did not have a significant fit. The model's predictive power was $85.0 \%$ and it had a correct classification of barebacking of $11.6 \%$.

\section{Discussion}

In this study of MSM recruited from a general gayinterest website, the sample of MSM was diverse with respect to their enacted sexual behaviours. Barebackers were more likely than men not reporting bareback sex to engage in a variety of sexual behaviours associated with higher risk for HIV/STI transmission.
Overall, although 'only' $10 \%$ of men indicated they engaged in bareback sex (discussed in [26]), the barebackers in this sample had a higher sexual risk profile, above and beyond barebacking, than other MSM as has been reported elsewhere $[6,7,24]$. This included nearly half $(47 \%)$ of barebackers reporting that last sexual encounter involved UAI, 40\% reporting that the last sexual encounter was with an unknown casual partner and many stating that it involved rimming, group sex, and taking semen in their mouth. Additionally, barebackers were more likely to report that the last sexual encounter was at a cruising location and multivariate analyses showed that those who reported using gay cruising places were almost twice as likely to engage in bareback sex compared to those who did not frequent such arenas. These findings may suggest, as Léobon and colleagues [8] found in their study of MSM in France, that barebackers have an adventure-oriented sexuality, characterised by sexual risk behaviours across multiple dimensions (acts, frequency, partners, setting) that place them at risk of infection. Indeed, qualitative research among MSM in New York City [27] found no distinctive patterns of factors motivating bareback sex, excepting libidinal and erotic desires that men could not or chose not to control. Other studies report similar findings $[3,6]$.

Consistent with previous empirical research $[7,24,28]$, findings in the present study also extend sexual health professionals' knowledge about the impact of the internet by demonstrating a relationship between barebacking and using the internet for sexual networking. The multivariate analysis showed that weekly use of gay chat rooms was associated with a two-fold increase in the odds of engaging in barebacking and barebackers were more likely than non-barebackers to report having found their last sexual partner through the internet. Also studies carried out in the United States (US) have affirmed the role of the internet in meeting bareback partners $[28,29]$. Among self-identified 
barebackers in New York City, 56\% met their last barebacking partner in an online chatroom or website. This venue also yielded the most number of partners [28]. As suggested by our own and other studies [7,29], the internet has become a social community in which many MSM are exposed to and comfortable in the context of sexual risk taking. Léobon and Frigault [23] found that among barebackers in France, the internet was the main environment used for seeking sexual encounters and they suggested that this behaviour was facilitated by specialised sex-oriented venues on the internet. In fact, while recognising that the serves as an important tool in the development of men's social and sexual identity, it has been suggested that the internet plays a growing role in facilitating sexual networking among MSM $[26,30]$. This may especially be the case for seropositive MSM. According to Elford and colleagues' [24] findings, HIV-positive MSM in London were more likely to find their HIV-positive bareback partners online, presumably because serostatus disclosure was easier online than offline.

Results from our present study show that a segment of MSM engaged in sex with women (almost one in five MSM), supporting earlier findings [7], and that barebackers relative to MSM not reporting this behaviour were significantly more likely to have sex with women. These men may represent an important epidemiological link between the broader MSM and heterosexual communities. Our previous research has suggested that many barebackers also do not identify as gay [26], mirroring results in the review by Millet et al [31], which concluded that a sizeable proportion of non-gay identified men of all ethnicities engage in homosexual sex and often do not disclose such behaviour to their female sex partners. That MSM in our study, especially barebackers, have sexual contact with both men and women increases the likelihood that these men may serve as bridge contacts, responsible for transmission of HIV and other STIs between sexual networks.

To this point, we have highlighted distinctions between barebackers and non-barebackers. On the other hand, it was encouraging that $44 \%$ of the sample had communicated about HIV with their last sexual partner. This fact, along with the previous points made, have bearing on future research and intervention initiatives, a point we address below. First, it must be highlighted that in multivariate analysis HIV testing was a significant predictor of barebacking. Barebackers not only reported more frequent HIV testing, but they were also more likely to have communicated about HIV-status with their most recent sexual partner, suggesting that these men negotiate safety around unprotected sex. Our quantitative results fit with a recent qualitative, US-based study, which also discovered that barebackers used strategies to "lessen risk of HIV transmission", such as strategic positioning and relying on knowledge of the reduced infectiousness of partners on successful antiretroviral treatments [5].
As described in this analysis of mostly Swedish MSM, profound differences between barebackers and MSM not reporting bareback sex were identified that may inform future data collection and prevention approaches. A first step is to document and understand the interplay between demographic, psychological, and sociocultural characteristics of barebackers in various areas of Europe, and other regions, using different recruitment strategies. This requires greater resolution about the definition of barebacking, perhaps best accessible through phenomenological research about the behaviour. Subsequent research should include more comprehensive qualitative and quantitative data collection to identify and understand risk trends among barebackers, as well as ways to reach these men, including those that may be harder to reach for outreach and intervention (e.g. those not identifying as gay), and to identify potential leverage points (i.e. changeable key mediators and moderators) to reduce the risk of HIV/STI exposure, infection, and reinfection. A consideration of barebacking as an indicator of behavioural intention to engage in UAI could be valuable, given that behavioural intention is a critical determinant of a person's behaviour [32]. Presently, while surveys have documented a general consensus concerning the main behavioural indicators for MSM, there is considerable diversity between EU/EEA countries [14] and intention is not incorporated. Additional work on relevant indicators in today's behavioural surveillance systems on MSM in Europe [14] as well as Global AIDS response progress reporting [16] seems valuable.

The lack of behavioural surveillance of sexual risks related to HIV and STIs among MSM [14], including barebacking, complicates both the estimation of developments across time and space, as well as the planning and evaluation of prevention programmes. Specifically, barebacking as a behaviour among European MSM has only recently, and limitedly, been explored in academic literature. The current analysis not only explored patterns of sexual behaviour and risk of barebackers and non-barebackers but also potential harm reduction strategies of barebackers, such as communicating about HIV status with sex partners. Future programmes must be appropriately tailored to meet the needs of barebackers, and, as other HIV prevention professionals $[4,5,27,33]$, we suggest that prevention campaigns focusing on barebackers should reinforce harm reduction, given that they seem to already incorporate it in their sexual liaisons. For example, barebackers reported communicating about HIV-status with their sex partners and frequently testing for HIV. Harm reduction strategies include not only open discussions about infection risks and sexuality with potential sex partners and frequent HIV/STI testing and monitoring of sexual health, but also limiting numbers of partners, serosorting, withdrawal before ejaculation, and strategic positioning. In studies of gay and bisexual men in the US, researchers $[5,29,34]$ identified serosorting and strategic positioning as 
frequently used harm reduction techniques among men who bareback. Carballo-Diéguez and colleagues' [27] point is well taken in that public health interventions directed at men who bareback must acknowledge the power of libidinal desires while seeking to encourage safer avenues for sexual satisfaction, including preor post-exposure prophylaxis. Another consideration for European HIV prevention responses is researchers' [5] warning that continued reliance on HIV prevention messages involving reiteration of risk could intensify barebackers' attachment to unsafe sexual behaviours. The researchers propose that health promoters instead work with the inner contradictions that barebackers express and facilitate spaces for men who bareback to discuss their behaviour and its justification [5].

Continuing from above, MSM who are unaware of their HIV-positive status contribute disproportionately to the transmission of HIV [17], thus testing and counselling may help prevent secondary transmissions. There is also a need for the development, implementation and evaluation of creative and scientifically sound offline, but perhaps particularly online, interventions to affect the diversity of MSM, to prevent a variety of risk behaviours and promote health among MSM. It is important to note here that it can be a challenge to reach high-risk MSM such as barebackers through intervention campaigns. Especially MSM who also have sexual relationships with women may not recognise themselves in HIV prevention programmes primarily targeting gay-identified men. Thus, it will be crucial to develop messages that can be accessed without publicly acknowledging homosexual behaviour, such as internet campaigns and posters placed in public places where men have sex, community-based health and social centres and popular gathering places within the broader community. In this sense, the joint work of the range of education and prevention professionals involved in the setting of MSM (e.g. non-governmental organisations, sexual health clinics, public health offices), not to mention barebackers and other MSM groups, represent a key way forward in the control of HIV/STIs among MSM. Such prevention initiatives have the potential to reduce the rate of new HIV infections among MSM and their partners, members of communities that currently carry a disproportionate burden of the HIV epidemic.

This study is not without limitations. First, the observed associations are based on cross-sectional data. Future studies using a prospective cohort design will be necessary to evaluate the significance and stability of sexual behaviours among barebackers over time. Although the internet provides a data collection mode that may minimise response bias among other limitations, these results remain based on self-reported data and their potential limitations. Another important caveat is that our non-random sample with participant self selection through the Qruiser website limits the ability to generalise the results to other MSM populations. Samples recruited through the internet have been found to be more urban, younger, single, and have higher education $[35,36]$. It is likely that men who are more closeted about their same-sex preference are less likely to visit gay websites and volunteer for research about MSM. In northern Europe, MSM seem to display sexual behaviours that differ from their counterparts in other countries, such as in the US (see e.g. [26]). These limitations notwithstanding, using 'last sexual encounter' as recall period likely minimised recall bias because it is a valid representation of sexual behaviours over longer periods of time [25]. Additionally, our data provide important insights into patterns of risk behaviour among not only an understudied group of MSM at elevated risk for HIV, but also among a northern European population disproportionately affected by HIV infection rates.

Acknowledgements:

The Swedish National Board of Health and Welfare and The Swedish Institute for Communicable Disease Control. 


\section{References}

1. Gendin S. Riding bareback: skin-on-skin sex, been there, done that, want more. POZ magazine. 1997;24: 64-5.

2. Carballo-Diéguez A, Ventuneac A, Bauermeister J, Dowsett GW, Dolezal C, Remien RH et al. Is 'bareback' a useful construct in primary HIV-prevention? Definitions, identity and research. Cult Health Sex. 2009;11(1):51-65. http:// dx.doi.org/10.1080/13691050802419467. PMid:19234950. PMCid:2669431.

3. Carballo-Diéguez A, Bauermeister J. “Barebacking”: Intentional condomless anal sex in HIV-risk contexts. Reasons for and against it. J Homosex. 2004;47(1):1-16. http://dx.doi. org/10.1300/Jo82V47n01_01. PMid:15189783.

4. Suarez T, Miller J. Negotiating risks in context: A perspective on unprotected anal intercourse and barebacking among men who have sex with men - where do we go from here? Arch Sex Behav. 2001;30(3):287-300. http://dx.doi. org/10.1023/A:1002700130455.

5. Frasca T, Ventuneac A, Balan I, Carballo-Diéguez A. Inner contradictions among men who bareback. Qual Health Res. 2012;22(7):946-56. http://dx.doi. org/10.1177/1049732312443592. PMid:22645221.

6. Mansergh G, Marks G, Colfax GN, Guzman R, Rader M, Buchbinder S. "Barebacking" in a diverse sample of men who have sex with men. AIDS. 2002;16(4):653-9. http://dx.doi. org/10.1097/00002030-200203080-00018. PMid:11873010.

7. Berg RC. Barebacking among MSM Internet users. AIDS Behav. 2008;12(5):822-33. http://dx.doi.org/10.1007/s10461-0079281-0. PMid:17676278.

8. Léobon A, Velter A, Engler K, Drouin M, Otis J. A relative profile of HIV-negative users of French websites for men seeking men and predictors of their regular risk taking: a comparison with HIV-positive users. AIDS Care. 2011;23(1):25-34. http://dx.doi. org/10.1080/09540121.2010.498866. PMid:21218274.

9. Berg RC. Barebacking: A review of the literature. Arch Sex Behav. 2009; 38(5):754-64. http://dx.doi.org/10.1007/s10508008-9462-6. PMid:19160033.

10. Halkitis PN, Wilton L, Galatowitsch P. What's in a term? How gay and bisexual men understand barebacking. J Gay Lesbian Psychother. 2005;9:35-48.

11. Huebner DM, Proescholdbell RJ, Nemeroff CJ. Do gay and bisexual men share researchers' definition of barebacking? J Psychol Human Sex. 2006;18:67-77. http://dx.doi.org/10.1300/ J056v18n01_04.

12. Wilton L, Halkitis PN, English G, Robertson M. An exploratory study of barebacking, club drug use, and meanings of sex in Black and Latino gay and bisexual men in the age of AIDS. J Gay Lesbian Psychother. 2005;9:49-72. http://dx.doi. org/10.1300/J236vo9no3_04.

13. European Centre for Disease Prevention and Control (ECDC)/ World Health organization (WHO) Regional Office for Europe. HIV/AIDS surveillance report in Europe 2010. Stockholm: ECDC 2011. Available from: http://ecdc.europa.eu/en/publications/ Publications/111129_SUR_Annual_HIV_Report.pdf

14. Elford J, Jeannin A, Spencer B, Gervasoni JP, van de Laar MJ, Dubois-Arber F et al. HIV and STI behavioural surveillance among Men who have Sex with Men in Europe. Euro Surveill. 2009;14(47). pii=19414. Available from: http://www. eurosurveillance.org/ViewArticle.aspx?Articleld=19414. PMid:19941807.

15. Dubois-Arber F, Jeannin A, Spencer B, Gervasoni JP, Graz B, Elford J, et al. Mapping HIV/STI behavioural surveillance in Europe. BMC Infectious Dis. 2010;10:290. http:// dx.doi.org/10.1186/1471-2334-10-290. PMid:20920339. PMCid:2959062.

16. The Joint United Nations Programme on HIV/AIDS (UNAIDS). Global AIDS response progress reporting 2012. Guidelines: Construction of core indicators for monitoring the 2011 political declaration on HIV/AIDS. Geneva: UNAIDS; 2011. Available from: http://www.unaids.org/en/media/ unaids/contentassets/documents/document/2011/ JC2215_Global_AIDS_Response_Progress_Reporting_en.pdf

17. Likatavicius G, Klavs I, Devaux I, Alix J, Nardone A. An increase in newly diagnosed HIV cases reported among men who have sex with men in Europe, 2000-6: implications for a European public health strategy. Sex Transm Infect. 2008; 84:499-505. http://dx.doi.org/10.1136/sti.2008.031419. PMid:19028955.

18. Dodd J, Mercey DE, Parry JV, Johnson AM. Increasing risk behaviour and high levels of undiagnosed HIV infection in a community sample of homosexual men. Sex Transm Infect. 2004; 80:236-40. http://dx.doi.org/10.1136/sti.2003.007286. PMCid:1744829.

19. Dougan S, Evans BG, Elford J. Sexually transmitted infections in Western Europe among HIV positive men who have sex with men. Sex Trans Dis. 2007;34(10):783-90. PMid:17495592.
20. MacDonald N, Dougan S, McGarrigle CA, Baster K, Rice B, Evans B. Recent trends in diagnosis of HIV and other sexually transmitted infections in England and Wales among men who have sex with men. Sex Transm Infect. 2004;80:492-97. http://dx.doi.org/10.1136/sti.2004.011197. PMid:15572622. PMCid:1744921.

21. Savage EJ, Hughes G, Ison C, Lowndes CM. Syphilis and gonorrhoea in men who have sex with men: A European overview. Euro Surveill. 2009; 14(47). pii=19417. Available from: http://www.eurosurveillance.org/ViewArticle. aspx?Articleld=19417

22. Velicko I, Arneborn M, Blaxhult A. Syphilis epidemiology in Sweden: re-emergence since 2000 primarily due to spread among men who have sex with men. Euro Surveill. 2008;13(5). pii=19063. Available from: http://www.eurosurveillance.org/ ViewArticle.aspx?Articleld=19063. PMid:19087867.

23. Léobon A, Frigault L. Frequent and systematic unprotected anal intercourse among men using the Internet to meet other men for sexual purposes in France: Results from the 'Gay Net Barometer 2006' survey. AIDS Care. 2008;20(4):478-84. http:// dx.doi.org/10.1080/09540120701868337. PMid:18449826.

24. Elford J, Bolding G, Davis M, Sherr L, Hart G. Barebacking among HIV-positive gay men in London. Sex Transm Dis. 2007;34(2):93-8. http://dx.doi.org/10.1097/01. olq.0000223247.68174.f9. PMid:16778742.

25. Younge SN, Salazar LF, Crosby RF, DiClemente RJ, Wingood GM, Rose E. Condom use at last sex as a proxy for other measures of condom use: Is it good enough? Adolescence. 2008; 43(172):927-31. PMid:19149154. PMCid:2701210.

26. Berg RC, Tikkanen R, Ross MW. Predictors of reporting bareback sex among a diverse sample of MSM recruited through a Swedish website. AIDS Care. 2011;23(12), 164451. http://dx.doi.org/10.1080/09540121.2011.565035. PMid:22117126.

27. Carballo-Diéguez A, Ventuneac A, Dowsett GW, Balan I, Bauermeister J, Remien $\mathrm{RH}$, et al. Sexual pleasure and intimacy among men who engage in 'bareback sex'. AIDS Behav. 2011; 15:S57-65. http://dx.doi.org/10.1007/s10461-011-9900-7. PMid:21380496. PMCid:3319084.

28. Halkitis PN. Behavioural patterns, identity, and health characteristics of self-identified barebackers: Implications for HIV prevention and intervention. J LGBT Health Res. 2007;3(1):37-48. http://dx.doi.org/10.1300/J463v03no1_05. PMid:18029314.

29. Grov C, DeBusk JA, Bimbi DS, Golub SA, Nanin JE, Parsons JT. Barebacking, the Internet, and harm reduction: An intercept survey with gay and bisexual men in Los Angeles and New York City. AIDS Behav. 2007;11:527-36. http://dx.doi.org/10.1007/ s10461-007-9234-7. PMid:17431756.

30. Halkitis PN, Parsons JT, Wilton L. Barebacking among gay and bisexual men in New York City: Explanations for the emergence of intentional unsafe behaviour. Arch Sex Behav. 2003;32(4):351-7. http://dx.doi.org/10.1023/A:1024095016181. PMid:12856896.

31. Millet G, Malebranche D, Mason B, Spikes P. Focusing 'down low': Bisexual black men, HIV risk and heterosexual transmission. J Natl Med Assoc. 2005;97(7):52 S-59S.

32. Monta-o DE, Kasprzyk D. The theory of reasoned action and the theory of planned behaviour. In Galz K, Rimer BK, Lewis FM, (editors). Health behavior and health education. Theory, research, and practice. 3rd ed. San Francisco: Jossey-Bass; 2002:67-98

33. Parsons JT, Bimbi DS. Intentional unprotected anal intercourse among men who have sex with men: Barebacking - from behavior to identity. AIDS Behav. 2007;11(2):277-87. http:// dx.doi.org/10.1007/s10461-006-9135-1. PMid:16775771.

34. Parsons JT, Schrimshaw EW, Wolitski RJ, Halkitis PN, Purcell DW, Hoff CC et al. Sexual harm reduction practices of HIVseropositive gay and bisexual men: serosorting, strategic positioning, and withdrawal before ejaculation. AIDS. 2005;19(suppl 1):S13-S25. http://dx.doi.org/10.1097/01. aids.0000167348.15750.9a. PMid:15838191.

35. Ross MW, Månsson SA, Daneback K, Cooper A, Tikkanen R. Biases in Internet sexual health samples: Comparison of an Internet sexuality survey and a national sexual health survey in Sweden. Soc Sci Med. 2005;61(1):245-52. http://dx.doi. org/10.1016/j.socscimed.2005.01.019. PMid:15847976.

36. Ross MW, Tikkanen R, Månsson SA. Differences between Internet samples and conventional samples of men who have sex with men: Implications for research and HIV interventions. Soc Sci Med. 2000;51:749-58. http://dx.doi.org/10.1016/ So277-9536(99)00493-1. 